Article

\title{
Evaluating the Impact of Corporate Governance on Firm Performance Using Board Index
}

\author{
Basil Okoth and Metin Coşkun \\ Institute of Social Sciences, Anadolu University, 26210 Tepebaşı/Eskişehir, Turkey \\ * Correspondence: basils.okoth@yahoo.com (B.O.); metincoskun@anadolu.edu.tr (M.C.)
}

\begin{abstract}
In 2013, the CMA at the İstanbul Stock Exchange increased the weight assigned to the Board of Directors component of its Corporate Governance Index to 35\% from the previous 25\%. Interpreting this as a recognition of the increasing vital role of the board, this study seeks to enhance the work of Abdığglu and Kılıç (2015) by putting more focus on the role of women in the boards and the effect of the busy chairman as well as the presence of outside directors on the effectivity of the Board. (The general business structure is associated with family owned groups and holdings which results into a network of intertwined board membership and cases of multiple directorship where, one board chairman can hold the same position or any directorship in as many as ten firmshence the busy chairman). I employ a different method of evaluating performance (EVA) together with the accounting measures of ROE and ROA (as opposed to the overused Tobin's Q), which I regress against the Board Index to be created. The focus is on firms on the BIST 100 index (excluding financial) between 2009 and 2013. The results reveal that the BINDEX has a significant and positive relationship with firm performance as measured by EVA. A second model reveals no relationship between the BINDEX and firm ROA, similar to the results of Kiliç and Abdioğlu (2015). ROA however has a positive relationship with the proportion of female directors in the board, as earlier reported by Lückerath- Rovers (2013). Another model using ROE as the proxy for performance registers a significant negative relationship with the index. The contradiction obtained in the results from these three models underscore the importance choosing the right methods when estimating the performance of a firm.
\end{abstract}

Keywords: corporate governance; EVA; board of directors; board index; EVA

\section{JEL Classification: C 19, G13, G 14}

NB: In the context of this article, the terms 'outside director' and 'independent director' are used interchangeably even though in theory these two terms tend to have slightly varied meanings depending on the defining body.

\section{Introduction}

Economic crises and various headline-catching company scandals (Enron and WorldCom) have caused renewed interest in Corporate Governance with every such occurrence acting as a reminder of the importance of Corporate Governance, often always followed by a series of steps of actions to be taken. CG has since ceased to be an interest topic only for academicians, but has become a subject of discussion in the media and other public fora with phrases like Corporate Fraud, organization failure, excessive compensation, Corporate Social Responsibility and lately, environment responsibility taking up lots of discussion room.

The TKYD defines CG as a set of standards that determine how a company is managed and controlled (monitored) in terms of policies and procedures, specifying the power play and roles of the management, the BOD and the shareholders. Many other definitions have been advanced in literature that make reference to the management and their obligation to satisfying the demands of the stakeholders, as well the possibility of their deviation from that mission, and the BOD and their 
duties with regards to monitoring the activities of the management as well as their responsibilities of protecting the position of the shareholders. The lack of a universal definition has led regulators in various countries to come up with codes and principles to define and monitor what qualifies and good corporate governance practices. The Turkish Capital Markets Boards (CMB), for instance, designed their principles and codes, in 2003. In 2007, ISE followed by incorporating within its ranks, a corporate governance index to measure performance in terms of price and returns of firms that claim compliance with the principles. The index includes firms

with a minimum CG score of 7/10 and at least 6.5 in each of the main sections. The rating is done by institutions incorporated by the $\mathrm{CMB}$ as agencies of determining the level of compliance within the regulations provided by the CMB.

The 2013 CMB regulations (act 36231672-410.99 (KBRT) - 267/3854) changed the Corporate Governance compliance weighting scheme for the four components of GC for the purpose of calculation for the index. The scheme hitherto ranked the components as Shareholders (25\%), Disclosure and Transparency (35\%), Stakeholders (15\%) and Board of Governance (25\%). However, the change effected 12.04.2013 changed the weights to Shareholders (25\%), Disclosure and Transparency (25\%), Stakeholders (15\%) and Board of Governance (35\%). This change did more to underscore the importance the exchange attaches to the role of the Board of Directors in the management of the shareholder' wealth and by extension shaping up the firm. Is the BOD really that important?

The Turkish corporate ownership structure is a complex hierarchical system built on the basis of Business Groups, holding companies and countless cases of cross-ownerships and is characterized by high levels of family ownerships and control. This eventually leads to a case of very smooth lines between the management and ownership. Research has attributed the management-ownership mix with reduced agency problems, and improved motivation among the management towards achieving a common goal. The family control system however trickles down to insider boards where the reigning families appoint their own, or affiliates to represent their interests on the boards.

Most of the BOD in the Turkish corporate are a representation of the ownership structure with shareholders nominating their preferred candidates to the board depending on their voting rights and ownership influence. Until the CMA codes specified the lower limits of independence in the $\mathrm{BOD}$, there was very little regard for outside independent directors in the boards. Owner families and/ or their associates command most of the boards with membership reported to be more than half (Yurtoğlu, 2003). This implies that the composition of the Turkish boards in terms of characteristics is and has been at the whim of the owner families and the majority shareholders. Also, it happens in several cases that the controlling group will entrust the same individuals to be in the numerous boards of the companies under their control, resulting into several interlocking board directorships among companies associated with a given BG or holding company.

Taking this into account, this study sought to study modelled an index on BOD characteristics and examined how these characteristics affect the firm's performance.

Extant research on CG has examined characteristics of the BOD with respect to performance as well as formulation of indices to make this comparison. These studies have resulted into conflicting results of positive, negative and no relationships. This study looked at the effect the BOD characteristics have on performance first by formulating an index based on selected characteristics of the board, which is regressed against performance. The second part involves examine the existence of a correlation between the 'busy chairman' and women as independent variables and performance. The study follows the work of Abdıoğlu and Kılıç (2015) in the construction of CG index with changes made on the board characteristics included. The characteristics considered include Board Size, CEO Duality, Gender Diversity, Independent Directors, Busy Chairman, Age and Board Committees. 


\section{Literature Review}

The ability of a board of directors to perform the functions depend largely on the characteristics and composition of the board itself. Their qualifications in terms of skills, experience and reputation; their election process; their affiliations and motives, and how they fit into the structure and strategic goal of the company among a host of other factors should be considered into great details when looking at the roles of the board. On this, we start from the position fronted by Kiel and Nicholson (2003) that larger companies tend to have equally larger boards, more directors holding multiple directorates, more outside directors and also tend to separate the positions of the chairman and CEO.

\section{Size of the Board}

Most studies cite lack of effective communication, increased costs and conflicts as the negative aspects of larger boards while smaller ones fail to reach the bar due to lack of enough necessary skills and experience. However, putting aside the delayed non-cohesive decisions and possible additional costs, larger boards have the capacity to 'accelerate' the performance of the company, especially in developing countries Malik et al. (2014). Guest (2009) points to a close cordial relationship between the directors (in a smaller board) giving room for free and inclusive contributions from all directors hence effective deliberations and concrete decisions. The lack or consensus persists in Turkey with Aygün, Taşdemir, \& Çavdar (2010), Doğan and Yildız (2013) registering a negative relationship in Turkish banks, whereas Okan et al. (2014) found a positive relationship.

\section{CEO Duality}

A dual CEO (A CEO who also chairs the board) is often viewed as an all-powerful director, a position viewed as a source of many agency problems on one side (where the board cannot effectively monitor the activities of the company), and as a source of effectiveness on the other hand (excess board autonomy may be seen as limiting on the tactics applied by the management in running the firm (Amba., 2014). While Brickley, Cole \& Jarrel (1997) associate separation of the roles with increase in costs such as information costs and inconsistent decision making Bathula, (2008) associates a dual CEO with strong leadership especially in small firms. Studies by both Acaravc1 et al. (2015) and Ersoy et al. (2011) in Turkey find positive relationship between CEO involvement in the board and performance, whereas the Corporate Governance Association of Turkey (TKYD) advocates for the separation of the CEO/Chairman positions. A single individual exercising both executive and auditing authorities may spell gloom to the company in terms of long term profitability and growth prospects (TKYD, 2011; 32).

\section{Gender Diversity on the Boards}

Gender is the most easily distinguishable and widely researched aspect of the diversity spectrum in the BOD. Women in the BOD means different perspectives and point of views on issues hence the potential to increase the value for shareholders according to the work of Campbell \& Mínguez- Vera, (2007). Both Terjesen et al. (2015) and Lückerath-Rovers (2013) positive relationship between the number of women on the board and the performance. A company with female board members exudes an image of innovation, modernity and a better understanding of the stakeholders, thus enjoys a raised standing. Adams and Ferreira (2009) find a negative relationship between gender diversity and firm performance (except in firms with weaker governance). Ararat, Aksu and Tansel Çetin (2010) associate diversity at the ISE with improved monitoring and reduced agency conflicts hence general positive performance. The Spencer Stuart Turkey Board Index survey of 2014 found that 
in the BIST 30 companies, only $9 \%$ of the board members are female; and out of this numbers $52 \%$ are members of the families that own these companies. These numbers fall way lower compared to other nations, hence the report recommends that the only reliable way of rectifying this is to employ enforced gender quotas.

\section{Busy Chairman}

The main concern of Research has always been when a director (chairman) takes up positions in other companies as well. How does this affect his performance in the focus company? Whereas a chairman with several directorship (or chairmanship) engagements may not be an effective monitor of the firm, his breath of experience from his other engagements are a source of immense value as an advisor to the CEO and the board. Busy independent directors are seen by controlling shareholders as a strategy or a means of consolidating control. Given a typical annual commitment of between 250300 hours (the chairman certainly has more time commitment than ordinary directors), a director with more than five appointments, for instance, would often be too preoccupied with work and would be less prepared for and inactive at meetings (ordinary or committee). This would reduce effort devoted to any of the boards (Adams, Hermalin \& Weisbach,

2008) and their capacity to offer any intelligent critique on issues presented by the management. Many codes provide that the chairman's other commitments should be disclosed on appointment, whereas the combined code (2006) clearly specifies that no one individual should hold two chairmanships of FTSE 100 companies. While one side of the argument goes to value interlocked directors for their inherent influential decision making abilities brought about by acquisition of crossfirm experience, expertize, business contact (denser networks) and reputation, there is a side that sees too much agency problems in their busyness (Tarkovska, 2012). Cashman, Gillan and Jun, (2012) find declining earnings and performance when a director is engaged in many boards.

In the Turkish structure of hierarchical ownerships centered on Business Groups and holding companies, it is not uncommon to find one individual acting as the chairman of the main and all the affiliate firms of the conglomerate, sometimes more than ten different companies at a time.

\section{Average Age}

Most corporate boards have been described as a 'country club for old boys' with a mostly white, male and a fairly aged membership over the years. Wegge et al. (2008) find a positive correlation between age diversity and performance in teams tasked with making complex decisions. Such diversities lead to a good balance between the experience and wisdom of the older directors and the energy, fresh ideas the future orientation of the younger ones (Ferrero-Ferrero, Fernández- Izquierdo \& MuñozTorres, 2015). In Turkey, Ararat et al (2010) find that 36.05\% of directors are between 50 and 60 years.

\section{Board Index (BINDEX)}

Borrowing form Abdıoğlu and Kılıç (2015), I formulated the Board index based on a slightly different set of characteristics of the board including Board Size, CEO Duality, Gender Diversity, Independent Directors, Busy Chairman, Age and Board Committees. 


\section{Data and Methodology}

This study draws its sample from firms registered at the BIST 100 index of the Istanbul Stock Exchange between 2009 and 2013. I excluded firms in the financial (banks, insurance companies and different funds) and real estate companies on account of the existence different governance codes under which they operate. Data for this study was obtained from publicly available sources including companies' Board Annual Operating Reports, Corporate Governance Compliance Reports and Financial Statements obtained from the respective company websites, the Public Disclosure Platform (KAP) of the Istanbul Stock Exchange and some were obtained from online datasets like Yahoo Finance, Investing.Com and Bigpara.

\section{Methodology}

\section{Variables}

Instead of the often used Tobin's Q, this study uses the more representative EVA as a means of evaluating the management efficiency and a measure of board effectiveness. Introduced by Stewart in 1991, EVA acts as an indicator for both retrospective and prospective evaluation of performance. It is considered to have advantages over other methodologies like Tobin's $Q$ by its ability to asses both the managerial and financial efficiency of an entity. Proponents of EVA prefer it based on its inclusive aspect of incorporating all costs of capital- both debts and equity. This essentially covers the inadequacies of other methodologies that only consider operational or net profits at the expense of the capital structure of the company (Akbaş, 2011). The formula used to calculate EVA in the study is similar to that used be Basti and Yilmaz (2013)

$$
E V A=N O P A T-\text { WACC } \times \text { Capital Invested }
$$

where, NOPAT is Net Operating Profit After Taxt, WACC is Weighted Average Cost of Capital. NOPAT is calculated by deducting tax from the Earnings Before Tax and Interest.

$$
\text { NOPAT }=E B I T-\text { Taxes }
$$

The invested capital is calculated by deducting all non-financial short term liabilities from total liabilities;

$$
\text { Capital Invested }=\text { Total Liabilities }- \text { Non-Financial Short Term Liabilities }
$$

NB: In the context of this study, non-financial short term liabilities is determined as what is left after deducting short term financial debts from total short term liabilities.

Other than EVA, both ROA and ROE are also used as measures of performance, where ROA is calculated as Net Income divided by Total Assets and ROE calculated by dividing net earnings by total equity.

The Board index is modelled following the works of Kiliç and Abdioğlu (2015) and Bushee et al (2010) by summing up seven different characteristics of the board (Board Size, CEO Duality, Gender Diversity, Independent Directors, Busy Chairman, Age and Board Committees) as proxies for CG.

Larger boards are associated with ineffective communication, increased costs and conflicts while smaller boards optimally between eight and nine allow for a close cordial relationship between the directors (Guest, 2009). The SIZE proxy is thus modelled around the given (Guest, 2009 and Tarkovska, 2012) optima with boards sized at 8 or 9 awarded 1 point, 10 and 11 awarded 0,5 whereas 12 and above results to zero points. Similarly, 6 and 7 are awarded 0,5 while 5 and below are awarded zero. A dual CEO is considered to be an all- powerful authority who has the ability to appoint his 
own preferred directors to the board hence control his own monitoring (Bathula, 2008). The index thus accepts CEO as a dummy variable represented by 1 in the case of a separate structure and 0 when the same individual performs both roles of the CEO and the Chairman. Gender diversity counts as an addition of wide breath of experience and knowledge as well as a way of socially legitimatizing the company. The proxy for Gender Diversity therefore is taken as the proportion of the number of female directors in the board (PFEM). Independent Directors are a source of strong monitoring and bring in fresh breath and perspective to the board. The proportion of independent directors is therefore taken as the proxy for independence (PNID). The chairman's engagement in more than one board expands the breadth of his knowledge and improves the flow of information. However, beyond a given limit, multiple engagements begin to hinder his ability to effectively perform his roles. The Busy Chairman (BCHAR) is modelled to reflect the Turkish structure where as many as fifteen multiple cases exist. Between 0-3 directorates is awarded 1 point, 4-7, 0.75 and 8-10, 0.5 .

11. Above 10 directorates is awarded 0 as beyond this point the chairman is in beyond his capacity to effectively participate in any of those boards. AGE represents the proportion of the directors who are above the age of 60 . Board Committee is represents the number of committees on the board and whether the said committee is headed by an independent director. Each of these factors is awarded a point each.

Two control variables are included, with SALES representing the size of the firm and age being measured for the time the firm was listed. The firm size, its diversification and the size of its leverage determines the size of its board (Yermack, 1996 and Coles et al 2008) and this may affect other factors such as the number of female directors and the number of committees in the board. AGE is the second control variable representing the duration in years that the firm has been listed in the stock exchange.

To establish the nature of the relationship that exists between the performance of the firms and the index, we regress EVA (the proxy of firm performance) against the B-index and three of the identified variables (PFEM, SIZE, and BCHAR) according to the model below:

$$
\text { EVAit }=\mathrm{C}+\text { BINDEXit }+ \text { PFEMit }+ \text { BCHARit }+ \text { SIZEit }+ \text { SALESit }+ \text { AGEit }+\varepsilon
$$

where BINDEX represents the board index, PFEM is the proportion of female directors in the board, $B C H A R$ is the proxy for a busy chairman with regards to the number of boards in which he has responsibilities either as chairman, executive or ordinary director. SIZE represents the number of directors in the board designed around an optimum number of 8 or 9 directors. SALES and AGE are the control variables, with the sales value being a representative of size and AGE is the duration the firm has been listed in the exchange.

The second group of tests in based on the two common accounting measures of performance i.e. ROA and ROE which are regressed against the BINDEX with the following models:

$$
\begin{aligned}
& \text { ROAit }=\text { C }+ \text { BINDEXit }+ \text { PFEMit }+ \text { BCHARit }+ \text { SIZEit }+ \text { SALESit }+ \text { AGEit }+\varepsilon \\
& \text { ROEit }=\text { C }+ \text { BINDEXit }+ \text { PFEMit }+ \text { BCHARit }+ \text { SIZEit }+ \text { SALESit }+ \text { AGEit }+\varepsilon
\end{aligned}
$$

The Hausman tests (Table II, III and IV) are not small enough to reject the null hypothesis hence the Random Effects model preferred.

\section{Model 1(EVA)}

Table V shows the Woodridge test for serial correlation for the first model, with significant results leading to the rejection of the null hypothesis and conclude that there is first-order autocorrelation. The Wald test also revealed the presence of heteroskedacity and thus I used the Feasible Generalized Least Squares to regress the variables.

Model 2 and 3 (ROA and ROE) are shown in Tables VII and VIII. 


\section{Empirical Findings}

The results for the first model is presented in Table VI, with the second and third models in Tables VII and VIII respectively. In model 1, I sought to examine the relationship between EVA as the proxy for firm performance and the proxy for Corporate Governance (BINDEX). The results reveal the existence of a strong positive relationship between EVA and BINDEX at 0.05 significance level. It is also observed that PFEM and BCHAR, despite not being of significant meaning to the model, are negative while SIZE is positive. The two control variables do not have any significant on the firm performance.

In model 2, a different aspect of firm performance measured by the firm's ROA is regressed against the index. Here however, similar to the results by Kiliç and Abdioğlu (2015), there is no significance relationship between the two variables. However, the results also reveal that the proportion of women in the board, represented in the model as PFEM is positively related to the firm performance (ROA). All the other variables considered did not have any significant effect on ROA.

Model 3 is shown in Table VIII, and shows a regression between ROE, as another proxy for firm performance, against the Board index. The model indicates the presence of a negative relationship between ROE and BINDEX. This contradicts expectations and theory which expect god Corporate Governance to be associated with increases in ROE.

\section{Conclusion.}

To determine whether the effectiveness of the board of directors (as a measure of Corporate Governance) with reference to its characteristics has any effect on the performance of the firm, I explored the relationship between the Board Index (BINDEX) and firm performance. The BINDEX is my design of a Corporate Governance index based on the characteristics of the board and in line with similar indices by Kiliç and Abdioğlu (2015) and Bushee et al (2010). The study by Kiliç and Abdioğlu (2015) examined a similar index (ISE 100), and similar time interval. To differentiate this study, I used a different and measure of performance (EVA) which is considered to be a more accurate measure of operational performance with regards to financial and managerial efficiency as well as a reflection of the shareholders wealth.

By considering a sample of the ISE 100 firms between 2009 and 2013, the results reveal that the BINDEX has a significant and positive relationship with firm performance as measured by EVA. This goes to express how important good Corporate Governance as represented by the board composition is to the shareholders. A second model reveals no relationship between the BINDEX and firm performance calculated using ROA. This is a reflection of the earlier results reported by Kiliç and Abdioğlu (2015). ROA however has a positive relationship with the proportion of female directors in the board, an observation similar to that of Lückerath-Rovers (2013), and lending credence to previous studies that related the presence of women with better monitoring. Another model using ROE as the proxy for performance registers a significant negative relationship with the index. The contradiction obtained in the results from these three models underscore the importance choosing the right methods when estimating the performance of a firm.

Lack of reliable data prevented the expansion of this study to cover more relevant variables and other aspects of the board. Most data relevant to Corporate Governance are only available in the firms after 2009 hence preventing the study for covering a larger sample. For future studies, I suggest expanding the period and variables. 


\section{Reference}

Abdioğlu, A., \& Kılıç, R. (2015). The Effect of Directors' Index on Firm Performance: An Evidence from BIST100 Firms. Eskìşehİr Osmangazi Üniversitesi İlbf Dergİsí, 10(1) 253-268.

Adams, R. B. and Ferreira, D. (2009). Women in the Boardroom and Their Impact an Governance and Performance, Journal of Financial Economics 94, 291-309

Adams, R. B., Hermalin, B. E., \& Weisbach, M. S.,(2008) The Role of Boards of Directors in Corporate Governance: A Conceptual Framework \& Survey. Charles A. Dice Center Working Paper No. 2008-21; ECGI - Finance Working Paper No. 228/2009; Fisher College of Business Working Paper No. 200803-020.

Akbaş, Halil Emre (2011), Ekonomik Katma Değer Yaklaşimi Ve Hissedar Değeri (Economic Value Added Approach And Shareholder Value), Mali Çözüm Dergisi V.106, pp 115-132.

Amba., S., Muni (2014). Corporate Governance and Firms' Financial PerformanceJournal of Academic and Business Ethics, Volume 8 - July, 2014

Ararat, M., Aksu, M. H. and Tansel Cetin, A., (2010), The Impact of Board Diversity on Boards' Monitoring Intensity and Firm Performance: Evidence from the Istanbul Stock Exchange.

Aygün, M., Taşdemir, A., \& Çavdar E. (2010), “Banka Performansı Üzerinde Yönetim Kurulu Büyüklügünün Etkisi", Atatürk Üniversitesi İktisadi ve İdari Bilimler Dergisi, Cilt:24, Sayı: 3.

Bastı, E., \& Yılmaz, T., (2013), İMKB'de İşlem Gören Yerli ve Yabancı İmalat Sanayi Şirketlerinin Ekonomik Katma Değer (EVA) ve Piyasa Katma Değerine (MVA) Dayalı Performans Analizi, Finans Politik \& Ekonomik Yorumlar Cilt: 50 Sayı: 578

Bathula, H. (2008). Board Characteristics and Firm Performance: Evidence from New Zealand. (phd), AUT University New Zealand.

Brickley, J. A., Cole, J. L., \& Jarrel. G., (1997) Leadership structure: Separating the CEO and Chairman of the Board, Journal of Corporate Finance 3 (1997) 189-220.

Campbell, K., \& Mínguez-Vera, A. (2007). Journal of Business Ethics, 83(3), 435-451.

Cashman, G. D., Gillan, S. L., \& Jun, C. (2012) Going Overboard? On Busy Directors and Firm Value, Journal of Banking \& Finance 36, 3248-3259

Coles, J., Daniel, N. \& Naveen, L. (2008). Boards: Does One Size Fit All? Journal of Financial Economics, Vol 87, 2, p 329-356.

Doğan Mesut \& YILDIZ Feyyaz (2013), The Impact of the Board of Directors' Size on the Bank's Performance: Evidence from Turkey, European Journal of Business and Management www.iiste.org Vol 5, 6

Ersoy, E., Bayrakdaroğlu, A., and Şamiloğlu, F. (2011) Türkiye'de Kurumsal Yönetim ve Firma Performansı (Tobin-Q ve Anormal Getiri) Arasındaki İlişkinin Analizi (The Analysis of the Relationship between Corporate Governance and Firm Performance (Tobin-q and Abnormal Return) in Turkey). Finans Politik E Ekonomik Yorumlar, 48(554), 2011, 71-83. 
Ferrero-Ferrero, I., Fernández-Izquierdo, M. Á. \& MuñozTorres M. J. (2015), Age Diversity: An Empirical Study in the Board of Directors, Cybernetics and Systems, 46:3-4, 249-270,

Guest Paul M. (2009), The Impact of Board Size on Firm Performance: Evidence from the UK,The European Journal of Finance, Vol 15 (4), Pages 385-404

Kiel Geoffrey C. and Nicholson Gavin J. (2003) Board Composition and Corporate Performance: How the Australian Experience Informs Contrasting Theories of Corporate Governance Corporate Governance, An International Review, 11(3) pp 189-205

Lückerath-Rovers, M., (2013), Women on Boards and Firm Performance, Journal of Management E Governance, Vol 17 (2) pp 491-509

Malik, M., Wan, D., Ahmad, M. I., Naseem, M. A \& Rehman, R. (2014), Role of Board Size in Corporate Governance and Firm Performance Applying Pareto Approach, Is It Cultural Phenomena, The Journal of Applied Business Research, (30), 5

Okan, T., Sarı, S. \& Nas, H. T. (2014), Yönetim Kurulu Yapisi Ile Finansal Performans Arasindaki Ilişkide Uluslararasi Çeşitlenmenin Aracilik Etkisi, İ. Ü. İşletme Fakültesi İşletme İktisadı Enstitüsü Yönetim Dergisi Yll : 25 Sayı.

Tarkovska V., (2012), Busy Boards, Corporate Liquidity And Financial Risk: Evidence from UK, Panel Data, European Financial Association (working paper)

TKYD, (2011) Corporate Governance Handbook Of Business Journalism, (Istanbul, Turkey), Corporate Governance Association of Turkey Publications

Wegge, J., Roth, C., Kanfer, R., Neubach, B., and Schmidt, K-H., (2008). Age and Gender Diversity as Determinants of Performance and Health in a Public Organization: The Role of Task Complexity and Group Size. Journal of Applied Psychology, 93 (6), p1301-1313.

Yermack David (1996), Higher Market Valuation of Companies With a Small Board of Directors Journal of Financial Economics 40 (2), Pages 185-211

Yurtoglu, B.B. (2003), “Corporate governance and implications for minority shareholders in Turkey", Journal of Corporate Ownership \& Control, Vol. 1 No. 1, pp. $72-86$.

(C) 2016 by the authors; licensee Preprints, Basel, Switzerland. This article is an open access article distributed under the terms and conditions of the Creative Commons by Attribution (CC-BY) license (http://creativecommons.org/licenses/by/4.0/). 